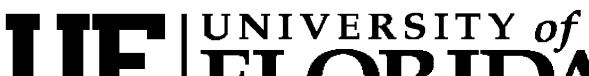 FLORIDA \\ IFAS Extension
}

\section{English Creek Native Tree and Plant Tour 1}

\author{
Michael G. Andreu, Melissa H. Friedman, and Mary E. Thornhill ${ }^{2}$
}

The English Creek Native Tree \& Plant Tour guidebook was created as an educational tool for a variety of audiences ranging from those with a general interest in plants to those who work with plants professionally. It is appropriate for natural resource professionals, teachers, naturalists, gardeners, school groups, and nature enthusiasts. The tour takes place along a raised boardwalk that crosses over the English Creek itself and is located at the English Creek Preserve in Hillsborough County, Florida. The guidebook can be used as a teaching aide or as a self-guided reference for identifying trees and plants along the trail. Since many of the plant species on this tour are typical of those found in riparian forests in central Florida, this guidebook can be used to help identify trees and plants in areas outside the Preserve.

\section{About the Preserve}

The English Creek Preserve consists of 380 acres of bottomland hardwood forests, pine flatwoods, and sandhills. Hillsborough Community College (HCC) purchased the first 120 acres in 1987 to use for environmental studies. Two years later, Hillsborough County Environmental Lands Acquisition and
Protection Program (ELAPP) purchased the remaining 260 acres to preserve and protect the north prong of the Alafia River, also known as English Creek.

The Preserve houses several species of birds, mammals, reptiles, amphibians, insects, and aquatic vertebrates and invertebrates. The federally endangered wood stork (Mycteria americana), state threatened gopher tortoise (Gopherus polyphemus), scarce eastern diamondback rattlesnake (Crotalus adamanteus), and eastern coral snake (Micrurus fulvius fulvius) are just a few of the species that have been documented on the property.

\section{History}

In 1865, after the American Civil War, this property and adjacent areas were used to establish homesteads for individuals freed from slavery. At the time, homesteads ranged from 40 to 160 acres, and settlers built homes and farmed the land. In 1868, settlers built the first church in the area, Antioch Baptist Church, which still exists outside the Preserve. Local lore has it that baptisms were performed in "Boiling Spring," the only spring located on the English Creek Preserve. Today, people

1. This document is FOR200, one of a series of the School of Forest Resources and Conservation Department, Florida Cooperative Extension Service, Institute of Food and Agricultural Sciences, University of Florida. Original publication date October 2008. Visit the EDIS Website at http://edis.ifas.ufl.edu.

2. Michael G. Andreu, assistant professor and extension specialist of forest systems, School of Forest Resources and Conservation, Gulf Coast Research and Education Center, Plant City, Florida; Melissa H. Friedman, biological scientist, School of Forest Resources and Conservation, Gulf Coast Research and Education Center, Plant City, Florida; and Mary E. Thornhill

The Institute of Food and Agricultural Sciences (IFAS) is an Equal Opportunity Institution authorized to provide research, educational information and other services only to individuals and institutions that function with non-discrimination with respect to race, creed, color, religion, age, disability, sex, sexual orientation, marital status, national origin, political opinions or affiliations. U.S. Department of Agriculture, Cooperative Extension Service, University of Florida, IFAS, Florida A. \& M. University Cooperative Extension Program, and Boards of County Commissioners Cooperating. Millie Ferrer-Chancy, Interim Dean 
still farm and raise cattle in areas surrounding the Preserve and remnants of these activities can be seen in the property`s uplands.

\section{Location and Access}

The English Creek Preserve is located in Hillsborough County, just north of SR 60 and west of County Line Road in the city of Bealsville. It is owned and managed by Hillsborough County ELAPP and $\mathrm{HCC}$ s Institute of Florida Studies (IFS), a community-based educational center designed for the study of ecology, biology, earth sciences, and Florida`s natural history.

In addition to nature trails, a seasonally flowing spring, and a raised boardwalk, English Creek has an Environmental Study Center that is jointly used by the IFS and the University of Florida for teaching, trainings, workshops, and special events. Access to the Preserve is available by appointment only, but use for educational activities and meetings is encouraged.

Make the most of your trip to English Creek! Bring binoculars for viewing wildlife (birds and mammals), walk along the unpaved hiking trails to the uplands, and visit the small seasonally flowing spring. Be sure to bring plenty of water and sunscreen, though, because these items are not sold at the Preserve.

We hope you enjoy your visit to the English Creek Preserve. Please help us in our efforts to protect and restore the Preserve by taking only pictures and leaving only footprints. Thank you for your cooperation and enjoy the beauty of one of Florida`s many riparian forests!

To arrange a visit to the English Creek Preserve and experience the English Creek Native Tree \& Plant Tour, please contact:

Dr. Sudeep Vyapari

Director and Program Manager

Institute of Florida Studies

Hillsborough Community College
1206 North Park Rd

Plant City, FL 33563

Email: svyapari@hccfl.edu

Phone: (813) 757-2144

Fax: (813) 757-2148

\section{Obtaining a Guidebook}

A copy of the English Creek Native Tree \& Plant Tour guidebook is available at the English Creek Preserve and can be obtained upon your scheduled visit. Alternatively, it can be downloaded from: http://www.hccfl.edu/departments/ifs/educationalresources.aspx and printed in advance.

\section{Printing and Assemblage Instructions}

For this document, double-sided printing works best, however, single-sided printing will also suffice. To assemble your guidebook, follow the steps below based on your method of printing. Then secure your guidebook by selecting from one of the options suggested in the "Secure Your Booklet" section.

Double-Sided Printing

1. Place top side of front page facing down so the "tour map" is facing up.

2. Stack pages 54 and 3 face down on top of the "tour map" page so that pages 4 and 53 are facing up.

3. Continue on this way by placing pages 52 and 5 face down so 6 and 51 are facing up, 8 and 49 are facing up, 10 and 47 are facing up, etc.

4. Once finished, stack the papers so their edges are aligned.

5. Bring the left edge of the stack to the right edge of the stack to fold the booklet in half. Take your thumbnail and slide it down the fold to make a crease. This is where the center line of the book will be. 
6. At this point your booklet is ready to use, however, you may want to secure your book so the pages stay in place. Try using one of the suggested methods in the "securing your booklet" section below.

\section{Single-Sided Printing}

1. The first page that prints should be the front and back cover. Turn this page over so that the blank side is facing you.

2. Fold this page by taking the left edge to meet the right edge (the front cover should now be facing you).

3. Open this page back up so the blank side is facing you again. Place the page with the "tour map" on top of this page; the map should be facing you and the blank sides of each paper should be touching.

4. Then, find the printed paper with page number " 3 " on it. Turn this paper over so that the blank side is facing you and stack it on top of the sheet with the "tour map."

5. Find the printed paper with page number " 4 " on it. Place this page (blank side down) on top of the blank page in front of you (blank sides of each paper should be touching again).

6. Continue these 2 steps for the remainder of the pages; 5 and 6 , then 7 and 8 , and so forth, until you have finished stacking all pages.

7. Once finished, stack the papers so their edges are aligned.

8. Bring the left edge of the stack to the right edge of the stack to fold the booklet in half. Take your thumbnail and slide it down the fold to make a crease. This is where the center line of the book will be.

9. At this point, your booklet is ready to use, however, you may want to secure your book so the pages stay in place. Try using one of the suggested methods in the "securing your booklet" section below.

\section{Secure Your Booklet}

1. Open the book so that all the pages are lying flat and pages 28 and 29 are facing you. Using a stapler, move down the center or crease of the booklet and place a staple parallel to the crease on the top, middle, and bottom of the center line. Once all the staples are in place, fold the stack so you are looking at your booklet again. Now it is ready for use.

\section{OR}

2. Have the book folded and placed so that only the front page is facing you. On the left side of the book where the crease occurs and about a 1/4 inch from the edge (towards the right side), make 3 holes spaced evenly apart on the top, middle, and bottom using a heavy duty hole puncher. Take some string (yarn works well) and place a 6-inch piece through each hole (still keeping the book closed) and tie a bow or knot in each hole. Once you have completed all three bows, your new book will be ready for use. 